\title{
A megújuló energiaforrásokkal foglalkozó Európai Uniós pályázatok térbeli jellegzetességei az Észak-Alföldi régióban a 2014-2020 közötti költségvetési periódusban \\ Spatial characteristics of European Union supported projects with the objective to enhance the dissemination of renewable energy resources in in the 2007-2013 budgetary period
}

\section{BADAR Z, KOZMA G ${ }^{1}$}

Debreceni Egyetem, Földtudományi Doktori Iskola, badzol1990@gmail.com

Debreceni Egyetem, Természettudományi és Technológiai Kar, Földtudományi Intézet, Társadalomföldrajzi és Területfejlesztési Tanszék, kozma.gabor@science.unideb.hu

\section{Absztrakt.}

Az elmúlt időszakban mind az Európai Unióban mind pedig Magyarországon egyre nagyobb hangsúlyt kapott a megújuló energiaforrások használata, és az elmúlt évtizedekben elért sikerekre támaszkodva mind az Európai Uniós, mind pedig a magyarországi fejlesztési dokumentumok egyre ambiciózusabb célokat fogalmaztak meg. A beruházások finanszírozásában igen fontos szerepet játszanak az Európai Uniós támogatások, és ennek szellemében a tanulmány célja Magyarország egyik konkrét térségben, az Észak-Alföldi régióban a megújuló energiaforrások felhasználását támogató, uniós forrást felhasználó projektek térbeli sajátosságainak a bemutatása. A kutatás eredményeként egyrészt három tényező befolyásoló szerepe mutatható ki. A társadalmi-gazdasági fejlettség hatása mind megyei, mind pedig járási szinten megfigyelhetö volt, emellett a települések esetében a lakosságszámot, illetve a közigazgatási szerepkört (járásközpont léte) lehet megemliteni. Másrészt a vizsgálat rávilágitott arra is, hogy a megújuló energiaforrások felhasználását támogató két operativ program (Terület- és Településfejlesztési Operativ Program, Környezeti és Energiahatékonysági Operativ Program) térbeli jellemzöi között is jelentös különbségekAbsztrakt magyarul.

Kulcsszavak: megújuló energiaforrások, Európai Uniós támogatások, Észak-Alföldi régió, területi sajátosságok

\section{Abstract.}

In the recent period, the use of renewable energy sources has received increasing emphasis both in the European Union and in Hungary. Building on the successes of the recent decades, the European Union and Hungarian documents have set increasingly ambitious objectives. European Union subsidies play a very important role in the financing of investments, and in the spirit of this, the aim of the study is to present the spatial characteristics of projects supporting the use of renewable energy sources in one specific region of Hungary, in the Northern Great Plain region. As a result of the research, on the one hand, the influencing role of three factors can be detected. The effect of socioeconomic development was observed at both county and district levels, and in the case of settlements the number of population and the administrative role (existence of a district center) can be mentioned. On the other hand, the study also revealed that there are significant differences between the spatial

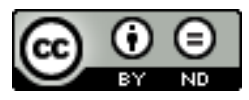


characteristics of the two operational programs supporting the use of renewable energy sources (Regional and Settlement Development Operational Program, Environmental and Energy Efficiency Operational Program).

Keywords: renewable energy resources, EU grants, spatial characteristics

JEL Kód: H76, N54, Q42, R58.

\section{Bevezetés, témafelvetés}

Az elmúlt időszakban mind az Európai Unióban mind pedig Magyarországon egyre nagyobb hangsúlyt kapott a megújuló energiaforrások használata. Az Európai Bizottság által 2010. márciusában nyilvánosságra hozott, majd az Európai Tanács által is elfogadott Európa 2020 (European Commission, 2010) stratégia célul tüzte ki, hogy 2020-ra a megújuló energiaforrások részesedése a végső energiafogyasztásban érje el a 20\%-ot, és a legfrissebb adatok alapján (2019 - 18,9\%) ezt többékevésbé sikerül is megvalósítani. Az évtizedben elért sikerekre támaszkodva a 2010-es évek közepén ugyanakkor újabb javaslatok is születtek: a „Clean energy for all Europeans package” keretében 2018ban elfogadott 2018/2001-es irányelv 2030-ra a 32\%-os arányt tüzte ki célul (Európai Unió Hivatalos Lapja, 2018).

A fentiekkel párhuzamosan Magyarország is törekszik a megújuló energiaforrások szerepének növelésére. Az Európa 2020 stratégia elérése érdekében az ország 14,65\%-os részesedést vállalt (a 2019-es érték 12,6\%, így kétséges a vállalás teljesítése), és hasonló értéket tartalmazott a 2010-ben elkészült Magyarország Megújuló Energia Hasznosítási Cselekvési Terve 2010-2020 (Nemzeti Fejlesztési Minisztérium, 2010) dokumentum is. Napjainkban - részben az Európai Uniós elvárásoknak köszönhetően - Magyarország is ambiciózusabb célokat fogalmazott meg: mind a 2020ben publikált Nemzeti Energiastratégia 2030 (Innovációs és Technológiai Minisztérium, 2020a) mind pedig a szintén 2020-ban megjelent Nemzeti Energia- és Klímaterv (Innovációs és Technológiai Minisztérium, 2020b) azt tartalmazta, hogy a megújuló energiaforrások részesedése a teljes energiafelhasználáson belül 2030-ra érje el a 21\%-ot.

A megújuló energiaforrások több szempontból is jelentős szerepet töltenek napjaink gazdaságitársadalmi életében, és ez a tény kiemelt fontosságúvá tette a velük kapcsolatos beruházások vizsgálatát. Egyrészt jelentős mértékben hozzájárulnak az üvegházhatású gázok kibocsájtásának, és ezáltal a globális felmelegedés veszélyének a csökkenéséhez (Blindheim, 2015; Mittal et al., 2016; Panwar et al., 2011; Squalli, 2017). Másrészt a nagy-erőmüvek centralizált jellegével szemben egy decentralizált rendszert alkotnak, és így elősegítik a biztonságos energia-ellátást (Brisbois, 2019; Gao et al., 2020; Gielen et al., 2019; Paladin et al., 2021). Harmadrészt különböző módszerekkel (pl. biomassza-termelés) táj- és vidékfejlesztési célok elérését is lehetővé teszik (Afsharzade et al., 2016; Benedek et al., 2018; Koncz - Nagyné Demeter, 2015; Krishan - Suhag, 2019; Michalkó et al., 2017; Woch et al., 2017).

Az elmúlt időszakban a Magyarországon megvalósított beruházások igen jelentős része az Európai Uniós támogatások révén valósult meg, és ennek következtében a kutatók nagy figyelmet szenteltek ezen pénzösszegek térbeli jellegzetességeinek a feltárására, amely elemzések több területre is kiterjedtek. A 2004 és 2015 közötti időszakban az összes uniós támogatás megoszlását elemző kutatás (Hajnal - Medve-Bálint, 2016) eredményei helyi szinten a gazdagabb, gazdaságilag és a civil szerveződések területén aktívabb, népesebb települések előnyét mutatták ki. A szerzők véleménye szerint megyei szinten bizonyos kompenzáció figyelhető meg: a megyei GDP értéke negatív, míg a munkanélküliség pozitív előjelü összefüggést jelzett az egy före jutó támogatások értékével. Az egyes operatív programok közötti különbségekre mutatott rá az encsi járásban elvégzett kutatás (Nemes et al., 2017), amely szerint a gazdaságfejlesztéshez kapcsolódó pályázatok (2007-2013 - GVOP, 20142020 - GOP) a járásközpontba és a járás déli részén elhelyezkedő, már eleve nagyobb gazdasági potenciállal rendelkező településekre, a környezetvédelmi pályázatok (KEOP) pedig a járásközpontba koncentrálódnak, míg a többi operatív program esetében sokkal egyenletesebb területi eloszlás volt megfigyelhetö. 
A turizmus területén a legfontosabb befolyásoló tényezőnek az adott térség turisztikai potenciálja és kisebb mértékben a társadalmi-gazdasági fejlettség szintje tekinthető (Gyurkó, 2020), és a legjobb értékekkel az Észak-magyarországi és a Dél-dunántúli és Balaton környéki megyék rendelkeztek. A munkaerőpiaci integrálódást segítő Európai Uniós támogatással megvalósuló képzések területiségét tekintve Borsod-Abaúj-Zemplén megyében kiemelkedő volt a megyeszékhelyt is magában foglaló Miskolci járás, valamint a tőle nyugatra elhelyezkedő járások szerepe (Hajdú, 2021). A mezőgazdaságban jelentős szeletét alkotó szőlészet-borászat ágazatba érkezett Európai Uniós források esetében zonális, a társadalomba jól beágyazódó, illetve lokális, mikroszinten jelentkező támogatások megkülönböztetését lehet megfigyelni (Járdány, 2021). Az előbbi elsősorban a Tokaji és az Egri borvidékre, valamint a Balatoni borrégió északi részére voltak jellemzők, míg az utóbbi domináltak többek között a Dél-Dunántúlon, a Mátrai és a Kunsági borvidéken.

A jelen tanulmány témájához legközelebb álló kutatás, az Európai Uniós támogatással a 2007-2013 közötti költségvetési időszakban megvalósult, megújuló energiaforrások felhasználását támogató források egész országra kiterjedő elemzése (Czimre et al., 2019) eredményeire támaszkodva több fontos következtetés is levonható. Egyrészt a fejletlenebb térségek (megyék) nagyobb pályázati aktivitást mutattak fel, a pályázati sikeresség tekintetében ugyanakkor a fejlettebb megyék rendelkeztek magasabb értékekkel. Másrészt a nyertes pályázatok esetében az adott területi egység (járások) fejlettsége és (települések) nagysága hatással volt a pályázatok átlagos nagyságára: a fejlettségi szint növekedésével csökkent, míg a településnagyság növekedésével pedig emelkedett a projektek átlagos nagysága.

A fentiek szellemében a tanulmány célja annak elemzése, milyen térbeli sajátosságai vannak a megújuló energiaforrások felhasználását segítő Európai Uniós támogatásoknak Magyarország egyik NUTS2 szintủ régiójában, az Észak-Alföldi régióban. A téma fontosságát az adja, hogy - mint korábbiakban már utaltunk rá - az elmúlt időszakban a Magyarországon megvalósult nagyobb összegü beruházások igen jelentős része uniós forrás felhasználásával valósult meg, és ez érvényes volt a megújuló energiaforrásokkal kapcsolatos fejlesztésekre is. A probléma különösen élesen vetődik fel a GDP/fö mutató alapján Magyarország legfejletlenebb térségének tekinthető Észak-Alföldi régióban, ahol a helyi szereplőknek csak korlátozottan állnak rendelkezésükre anyagi erőforrások az ilyen jellegü beruházások önerőből történő megvalósítására. Ennek szellemében a tanulmány - igazodva a hazai szakirodalom által is tárgyalt felvetésekhez - az alábbi kérdésekre keresi a választ:

- melyek azok társadalmi-gazdasági és politikai (közigazgatási) tényezők, amelyek befolyásolják a támogatások térbeli eloszlását;

- milyen különbségek figyelhetők meg az egyes operatív programok között.

\section{Anyag és módszer}

A kutatás a palyazat.gov.hu honlapon elérhető információkra támaszkodott, amelyek pályázati konstrukciókként tartalmazták az egyes projektek és pályázók nevét, a megvalósítás helyszínét és az Európai Uniós támogatás összegét (a kutatás során csak ezt az értéket, vagyis a megítélt támogatás nagyságát vettem figyelembe). A 2014-2020 közötti Európai Uniós költségvetési periódusban alapvetően két operatív programból kerültek finanszírozásra a megújuló energiaforrásokkal kapcsolatos pályázatok. Egyrészt a Környezeti és Energiahatékonysági Operatív Programot (későbbiekben KEHOP) kell megemlíteni, amelynek 5. prioritási tengelye (Energiahatékonyság növelése, megújuló energiaforrások alkalmazása) foglalkozott ezzel a témakörrel. A másik forrást a Terület- és Településfejlesztési Operatív Program (későbbiekben TOP) jelentette, amely esetében a 3. prioritási tengely (Alacsony szén-dioxid kibocsátású gazdaságra való áttérés kiemelten a városi területeken), valamint a megyei jogú városokra vonatkozó 6. prioritási tengely (Fenntartható városfejlesztés a megyei jogú városokban) keretében hirdettek meg ezt a célt szolgáló pályázati konstrukciókat (1. táblázat). A három prioritási tengelybe tartozó pályázati lehetőségek között jelentős különbségnek lehetett tekinteni, hogy az elsőre az egész országból érkezhettek pályázatok, a második esetében az egyes megyéknek (így a vizsgált három megyének) is saját kerete volt, amelyre csak abból a területi egységből pályázhattak, míg a harmadik esetében az érintett három település (Debrecen, Nyíregyháza és Szolnok) helyi önkormányzata adhatott be pályázatot. Emellett a Környezeti és 
Energiahatékonysági Operatív Program esetében költségvetési intézmények, egyházak és vállalkozások adhattak be a pályázatokat, míg a Terület- és Településfejlesztési Operatív Programnál helyi önkormányzatok voltak a pályázók.

1. táblázat: A vizsgálat során figyelembe vett pályázati konstrukciók

Table 1: Tender constructions taken into account in the analysis

\begin{tabular}{|l|l|}
\hline $\begin{array}{l}\text { a pályázati } \\
\text { konstrukció száma }\end{array}$ & a pályázati konstrukció neve \\
\hline KEHOP-5.1.1. & $\begin{array}{l}\text { Megújuló alapú zöldáram-termelés elösegítése 4 MW beépített } \\
\text { teljesítményt meghaladó villamosenergia termelö rendszerek telepítésével }\end{array}$ \\
\hline KEHOP-5.1.2. & $\begin{array}{l}\text { Megújuló alapú zöldáram-termelés elösegítése 0,5 MW beépített } \\
\text { teljesítményt nem meghaladó villamosenergia termelö rendszerek } \\
\text { telepítésével }\end{array}$ \\
\hline KEHOP-5.2.10. & Költségvetési szervek pályázatos épülletenergetikai fejlesztései \\
\hline KEHOP-5.2.11. & Fotovoltaikus rendszerek kialakítása központi költségvetési szervek részére \\
\hline KEHOP-5.2.13. & Pályázatos épületenergetikai felhivás egyházak számára \\
\hline KEHOP-5.2.2. & Középületek kiemelt épületenergetikai fejlesztései \\
\hline KEHOP-5.2.3. & $\begin{array}{l}\text { Egyházak épületenergetikai fejlesztései megújuló energiaforrás } \\
\text { hasznosításának lehetöségével }\end{array}$ \\
\hline KEHOP-5.2.5. & Közel nulla energiaigényü épületek létesitése mintaprojekt jelleggel \\
\hline KEHOP-5.3.2. & Helyi hö és hütési igény kielégítése megújuló energiaforrásokkal \\
\hline TOP-3.2.1. & Önkormányzati épületek energetikai korszerüsitése \\
\hline TOP-3.2.2. & $\begin{array}{l}\text { Önkormányzatok által vezérelt, a helyi adottságokhoz illeszkedö, megújuló } \\
\text { energiaforrások kiaknázására irányuló energiaellátás megvalósitása, } \\
\text { komplex fejlesztési programok keretében }\end{array}$ \\
\hline TOP-6.5.1. & Önkormányzati épületek energetikai korszerüsitése \\
\hline
\end{tabular}

Forrás: palyazat.gov.hu

A pályázati konstrukciók egy része (az 1. táblázatban ezek dőlt betűvel vannak jelölve) esetében problémát jelentett, hogy azok keretében a megújuló energiaforrások alkalmazását elősegítő beruházások mellett egyéb energetikai jellegü fejlesztéseket (pl. hőszigetelés, nyílászáró-csere) is támogattak. Az érintett pályázatok nyilvános adatlapját átvizsgálva ugyanakkor meg lehetett állapítani, hogy a megújuló energiaforrásokkal kapcsolatos beruházások (döntő mértékben a napenergia használatának a támogatása) igen fontos alkotóelemeik voltak, ezért az elemzés során ezeket is figyelembe vettük.

A településekre és járásokra vonatkozó információkat az Országos Területfejlesztési és Területrendezési Információs Rendszer (TEIR) adatbázisából gyűjtöttük ki.

\section{Eredmények és következtetések}

A megújuló energiaforrásokkal kapcsolatos pályázatok Észak-Alföldi régióbeli általános helyzetét vizsgálva (2. táblázat) megállapítható, hogy összesen 403 pályázat valósult meg, amelyek révén több mint 70 milliárd Ft támogatás érkezett a térségbe. A pályázatok döntő része (több mint $80 \%$-a) a Terület- és Településfejlesztési Operatív Program keretében valósult meg (ezen belül is a legfontosabb szerepet az „Önkormányzati épületek energetikai korszerüsítése” konstrukció játszotta), és a támogatások nagyobbik fele $(61,3 \%$-a) is ehhez kötődött. 
2. táblázat: A megújuló energiaforrásokkal kapcsolatos pályázatok általános jellegzetességei az Észak-Alföldi régióban a 2014-2020 közötti Európai Uniós költségvetési periódusban

Table 2: General characteristics of tenders related to renewable energy sources in the Northern Great Plain region during the 2014-2020 European Union budget period

\begin{tabular}{|l|c|c|c|}
\hline $\begin{array}{l}\text { pályázati } \\
\text { konstrukció }\end{array}$ & $\begin{array}{c}\text { nyertes pályázatok } \\
\text { száma }(\mathrm{db})\end{array}$ & $\begin{array}{c}\text { összes támogatás } \\
(\text { millió } \mathrm{Ft})\end{array}$ & $\begin{array}{c}\text { átlagos projektnagyság } \\
\text { (millió Ft/projekt) }\end{array}$ \\
\hline KEHOP-5.1.1. & 0 & 0 & 0 \\
\hline KEHOP-5.1.2. & 1 & $2.100,0$ & $2.100,0$ \\
\hline KEHOP-5.2.10. & 14 & $1.752,1$ & 125,2 \\
\hline KEHOP-5.2.11. & 20 & $3.601,3$ & 180,1 \\
\hline KEHOP-5.2.13. & 11 & $2.341,6$ & 212,9 \\
\hline KEHOP-5.2.2. & 20 & $12.498,9$ & 624,9 \\
\hline KEHOP-5.2.3. & 20 & $3.650,0$ & 182,5 \\
\hline KEHOP-5.2.5. & 2 & $1.450,0$ & 23,0 \\
\hline KEHOP-5.3.2. & 2 & 468,8 & $\mathbf{3 0 9 , 6}$ \\
\hline KEHOP összesen & $\mathbf{9 0}$ & $\mathbf{2 7 . 8 6 2 , 7}$ & 100,3 \\
\hline TOP-3.2.1. & 253 & $25.383,7$ & 257,2 \\
\hline TOP-3.2.2. & 19 & $4.886,9$ & 337,8 \\
\hline TOP-6.5.1. & 41 & $13.851,4$ & $\mathbf{1 4 1 , 0}$ \\
\hline TOP összesen & $\mathbf{3 1 3}$ & $\mathbf{4 4 . 1 2 2 , 0}$ & \\
\hline
\end{tabular}

Forrás: palyazat.gov.hu alapján saját szerkesztés

A pályázatok térbeliségének vizsgálata során az első körben a régió és az azt alkotó megyék országon belüli helyzetét vizsgáltuk (3. táblázat), és ennek keretében azt elemeztük, mennyire volt aktívak és eredményesek a Környezeti és Energiahatékonysági Operatív Programom keretében meghirdetett pályázati konstrukciók vonatkozásában (ezen operatív program esetében „országos” verseny volt és ennek következtében fontos a régió helyzetének a feltárása).

3. táblázat: Az Észak-Alföldi régió és az azt alkotó megyék helyzete a Környezeti és Energiahatékonysági Operativ Programom belül a 2014-2020 közötti Európai Uniós költségvetési periódusban (2017. január 1-i állandó népességgel számolva)

Table 3: Situation of the Northern Great Plain region and its constituting counties within the Environment and Energy Efficiency Operational Programme during the 2014-2020 European Union budgetary period (calculated with the number of population of 1 January 2017 as a permanent value)

\begin{tabular}{|l|c|c|c|c|c|}
\hline & $\begin{array}{c}\text { Hajdú-Bihar } \\
\text { megye }\end{array}$ & $\begin{array}{c}\text { Jász-Nagykun- } \\
\text { Szolnok megye }\end{array}$ & $\begin{array}{c}\text { Szabolcs-Szatmár- } \\
\text { Bereg megye }\end{array}$ & $\begin{array}{c}\text { Észak-Alföldi } \\
\text { Régió }\end{array}$ & $\begin{array}{c}\text { Magyar- } \\
\text { ország }\end{array}$ \\
\hline $\mathrm{A}(\mathrm{db})$ & 8,05 & 10,11 & 9,05 & 8,96 & 8,53 \\
\hline $\mathrm{B}(\%)$ & 61,4 & 53,8 & 79,2 & 66,2 & 61,4 \\
\hline $\mathrm{C}(\%)$ & 48,0 & 35,0 & 66,5 & 53,2 & 70,9 \\
\hline $\mathrm{D}$ (millió Ft) & 219,1 & 247,1 & 399,0 & 309,6 & 471,1 \\
\hline
\end{tabular}

A - a 100.000 före jutó beadott pályázatok száma a Környezeti és Energiahatékonysági Operatív Program (KEHOP) esetében, B - pályázati eredményesség (nyertes pályázatok száma/beadott pályázatok száma; \%) a Környezeti és Energiahatékonysági Operatív Program (KEHOP) esetében, $C$ - pályázati eredményesség (elnyert összeg/igényelt összeg; \%) a Környezeti és Energiahatékonysági Operatív Program (KEHOP) esetében, D átlagos projekt-nagyság (millió Ft)

Forrás: palyazat.gov.hu és a teir.hu alapján saját számitás

A pályázati aktívitás vonatkozásában megállapítható, hogy a régióból relatíve (100.000 fôre vetítve) több pályázat érkezett, mint országos szinten, és hasonló pozitív (az országos átlagnál jobb érték) tény figyelhető meg az elnyert pályázatok arányát tekintve is. Pénzügyi vonatkozásban (elnyert összeg/igényelt összeg, átlagos projektnagyság) esetében ugyanakkor az Észak-Alföldi régió helyzete nem tekinthető kedvezőnek: egyrészt a pályázók az igényelt összeg alig több, mint 50\%-át nyerték el, másrészt a megvalósult projektek nagysága is elmaradt az országos átlagtól, és ez a tény igaz volt 
mind a három megyére. Az érintett mutatók döntő részénél Szabolcs-Szatmár-Bereg megye rendelkezett a legjobb mutatókkal, amely mögött az a tény állhat, hogy a helyi szereplők - a megye elmaradottságából fakadó saját erőforrás-hiány miatt - különösen nagy figyelmet fordítottak minél nagyobb összegü források megszerzésére.

Az elemzés következő szintjét a járások jelentették, amelyek esetében elősorban azt vizsgáltuk, hogyan befolyásolja a társadalmi-gazdasági fejlettség a nyertes pályázatok jellegzetességeit (4. táblázat). A 4. táblázat adatai meggyőzően mutatják, hogy a fejletlenebb térségekbe relatíve (egy állandó lakosra számítva) nagyobb támogatás érkezett, amely arra utal, amely tény - a projektek révén keletkező energia-megtakarításkövetkeztében - jelentős segítséget jelentett a helyi szereplők számára. A projektek átlagos nagyságát tekintve ugyanakkor nem figyelhető meg egyértelmű tendencia: magas, illetve alacsony értékek is jellemzőek mind a fejlett, mind pedig a fejletlen járásokra.

4. táblázat: A megújuló energiaforrások elterjedését szolgáló nyertes pályázatok jellegzetességei a járások fejlettségének a függvényében a 2014-2020 közötti költségvetési idöszakban az Észak-Alföldi régióban

Table 4 Characteristics of the winning applications related to renewable energy sources based on the development level of the districts in the 2014-2020 budgetary period in the Northern Great Plain region

\begin{tabular}{|l|c|c|}
\hline & A & B \\
\hline első hatod & 30.674 & 99,48 \\
\hline második hatod & 34.168 & 149,09 \\
\hline harmadik hatod & 25.931 & 93,98 \\
\hline negyedik hatod & 26.533 & 112,76 \\
\hline ötödik hatod & 24.439 & 127,04 \\
\hline hatodik hatod & 15.944 & 108,81 \\
\hline
\end{tabular}

$A$ - egy lakosra jutó pályázati összeg (Ft), $B$ - a pályázatok átlagos nagysága (millió Ft/db)

elsö hatod-legfejletlenebb járások, hatodik hatod-legfejlettebb járások

Forrás: palyazat.gov.hu alapján saját szerkesztés, 290/2014. (XI. 26.) kormányrendelet a kedvezményezett járások besorolásáról

A települések helyzetének elemzése során két témakörre koncentráltunk, vizsgáltuk a településnagyság és a közigazgatási szerepkör befolyásoló szerepét. A településnagyság esetében igen jelentős különbségek figyelhetők meg a Terület- és Településfejlesztési Operatív Program (5. táblázat) és a Környezeti és Energiahatékonyság Operatív Program (6. táblázat) között. Az előző esetében (az 5. táblázat nem tartalmazza a megyeszékhelyek adatait, mivel azok elöre meghatározott támogatási összegben részesültek) az adatokból két fontos következtetés vonható le. Egyrészt a kisebb (elsősorban a 2.000 fönél alacsonyabb lakosságszámú) települések a támogatásokból nagyobb arányban részesültek, mint az állandó népességből való részesedésük, míg a nagyobb (főleg az a 10.000 főnél népesebb) települések esetében fordított volt a helyzet. Ennek hátterében elsősorban az áll, hogy az érintett jellegü fejlesztések megyén belüli „elosztása” során igyekeztek minél több települést bevonni, és ezen pályázatok potenciális „,célterületei”, az önkormányzati épületek, minden településen rendelkezésre álltak. Másrészt az egy projektre jutó támogatások nagyságát tekintve a településnagyság növekedésével a támogatás nagysága is emelkedik, amely arra vezethető vissza, hogy a népesebb településeken elhelyezkedő épületek nagyobb méretüek/alapterületüek, és ezért korszerúsítésük is többe kerül. A három megye adatait elemezve a legnagyobb eltérés SzabolcsSzatmár-Bereg megye esetében figyelhető meg (a támogatásokból a legkisebb települések magas, míg a legnagyobb települések alacsony értéke), amely alapvetően a megye településhálózati sajátosságával magyarázhatók: az összes település több mint 1/3-ának (37,1\%-a) alacsonyabb a lakosságszáma, mint 1.000 fö. 
5. táblázat: A Terület-és Településfejlesztési Operativv programból finanszirozott pályázatok jellegzetességei az Észak-Alföldi régióban a 2014-2020 közötti Európai Uniós költségvetési periódusban a különbözö

lakosságszámú településeken (2017. január 1-i állandó népességgel számolva)

Table 5: Characteristics of the applications financed by the Regional and Settlement Development Operational

Programme in the Northern Great Plain region during the 2014-2020 budgetary period by settlements of varying population

\begin{tabular}{|c|c|c|c|c|}
\hline megye & lakosságszám & $\mathrm{A}$ & B & $\mathrm{C}$ \\
\hline \multirow{5}{*}{$\begin{array}{l}\text { Hajdú- } \\
\text { Bihar } \\
\text { megye }\end{array}$} & kevesebb, mint 1.000 fö & 5,3 & 3,5 & 79,3 \\
\hline & $1.000-2.000$ fö & 9,3 & 7,8 & 99,6 \\
\hline & $2.000-5.000$ fó & 26,9 & 20,8 & 134,1 \\
\hline & $5.000-10.000$ fö & 26,0 & 24,9 & 215,6 \\
\hline & 10.000 fönél több & 32,5 & 43,0 & 168,9 \\
\hline \multirow{5}{*}{$\begin{array}{l}\text { Jász- } \\
\text { Nagykun } \\
\text { Szolnok } \\
\text { megye }\end{array}$} & kevesebb, mint 1.000 fó & 9,8 & 2,4 & 60,5 \\
\hline & $1.000-2.000$ fö & 23,2 & 10,5 & 74,2 \\
\hline & $2.000-5.000$ fö & 16,1 & 20,7 & 81,9 \\
\hline & $5.000-10.000$ fö & 22,7 & 28,5 & 93,3 \\
\hline & 10.000 fönél több & 28,2 & 37,9 & 162,3 \\
\hline \multirow{5}{*}{$\begin{array}{l}\text { Szabolcs- } \\
\text { Szatmár- } \\
\text { Bereg } \\
\text { megye }\end{array}$} & kevesebb, mint 1.000 fö & 15,0 & 10,6 & 72,6 \\
\hline & $1.000-2.000$ fö & 23,4 & 21,5 & 86,3 \\
\hline & 2.000-5.000 fö & 33,2 & 34,9 & 110,9 \\
\hline & $5.000-10.000$ fö & 19,4 & 17,4 & 209,2 \\
\hline & 10.000 főnél több & 9,0 & 15,6 & 213,0 \\
\hline \multirow{5}{*}{$\begin{array}{l}\text { Észak- } \\
\text { Alföldi } \\
\text { régió }\end{array}$} & kevesebb, mint 1.000 fö & 11,1 & 6,1 & 69,7 \\
\hline & $1.000-2.000$ fö & 19,8 & 14,2 & 83,1 \\
\hline & $2.000-5.000$ fó & 26,7 & 26,6 & 108,9 \\
\hline & $5.000-10.000$ fö & 21,9 & 22,8 & 153,9 \\
\hline & 10.000 fönél több & 20,5 & 30,3 & 180,6 \\
\hline
\end{tabular}

$A$ - a támogatásokból való részesedés (\%), B - az állandó népességböl való részesedés (\%), $C$ - az egy projektre jutó támogatás nagysága (millió Ft)

Forrás: palyazat.gov.hu és a teir.hu alapján saját számítás

A Környezeti és Energiahatékonysági Operatív Program esetében eltérő folyamatok figyelhetők meg (6. táblázat).

6. táblázat: A Környezeti és Energiahatékonysági Operativ programból finanszirozott pályázatok jellegzetességei az Észak-Alföldi régióban a 2014-2020 közötti Európai Uniós költségvetési periódusban a különbözö nagyságú településeken (2017. január 1-i állandó népességgel számolva)

Table 6: Characteristics of the applications financed by the Environment and Energy Efficiency Operational

Programme in the Northern Great Plain region during the 2014-2020 budgetary period by settlements of varying population

\begin{tabular}{|l|c|c|c|c|c|c|c|c|}
\hline \multirow{2}{*}{ lakosságszám } & \multicolumn{2}{|c|}{$\begin{array}{c}\text { Hajdú-Bihar } \\
\text { megye }\end{array}$} & \multicolumn{2}{c|}{$\begin{array}{c}\text { Jász-Nagykun- } \\
\text { Szolnok megye }\end{array}$} & \multicolumn{2}{c|}{$\begin{array}{c}\text { Szabolcs-Szatmár- } \\
\text { Bereg megye }\end{array}$} & \multicolumn{2}{c|}{$\begin{array}{c}\text { Észak-Alföldi } \\
\text { régió }\end{array}$} \\
\cline { 2 - 10 } & $\mathrm{A}$ & $\mathrm{B}$ & $\mathrm{A}$ & $\mathrm{B}$ & $\mathrm{A}$ & $\mathrm{B}$ & $\mathrm{A}$ & $\mathrm{B}$ \\
\hline $\begin{array}{l}\text { kevesebb, mint } \\
1.000 \text { fö }\end{array}$ & 0,0 & 2,2 & 0,0 & 1,9 & 0,0 & 8,4 & 0,0 & 4,5 \\
\hline $1.000-2.000$ fö & 0,0 & 4,9 & 0,0 & 8,5 & 7,7 & 17,1 & 4,7 & 10,5 \\
\hline $2.000-5.000$ fö & 0,0 & 13,0 & 3,4 & 16,9 & 10,1 & 27,8 & 6,7 & 19,7 \\
\hline $5.000-10.000$ fö & 7,8 & 15,6 & 7,6 & 23,2 & 13,2 & 13,8 & 11,0 & 16,8 \\
\hline 10.000 fönél több & 14,9 & 27,0 & 34,6 & 30,9 & 31,5 & 12,5 & 28,6 & 22,4 \\
\hline megyeszékhely & 77,3 & 37,3 & 54,4 & 18,6 & 37,5 & 20,5 & 49,1 & 26,1 \\
\hline
\end{tabular}

$A$ - a támogatásokból való részesedés (\%), $B$ - az állandó népességből való részesedés (\%),

Forrás: palyazat.gov.hu és a teir.hu alapján saját számitás 
Egyrészt a kisebb településeken alig valósultak meg ilyen jellegü fejlesztések, míg ezzel a szemben a nagyobb lakosságszámú települések, és különösen a megyeszékhelyek részesedése átlagon felülinek tekinthető. Ennek hátterében elsősorban az állt, a KEHOP-pályázatok keretében elsősorban olyan épületekkel (pl. kormányhivatalok, közép- és felsőoktatási intézmények, kórházak, rendőrkapitányságok) kapcsolatos beruházásokat támogatták, amelyek döntő mértékben a nagyobb lakosságszámú településeken találhatók.

A közigazgatási jogállás esetében a legfontosabb kérdés az volt, hogyan befolyásolja a támogatások megoszlását az érintett települések járásközponti szerepköre. A Terület- és Településfejlesztési Operatív Program esetében (7. táblázat) továbbra is megfigyelhető a területi decentralizációra való törekvés: régiós szinten a járásközpontok támogatásokból való részesedése alacsonyabb, mint az állandó népességből való arányuk. A megyék helyzetét vizsgálva a különbség a legnagyobb JászNagykun-Szolnok megye esetében, ugyanakkor Szabolcs-Szatmár-Bereg megyénél a támogatások vonatkozásában már a járásközpontok kiemelt kezelése állapítható meg.

7. táblázat: A Terület- és Településfejlesztési Operatív Programból finanszírozott pályázatok jellegzetességei az Észak-Alföldi régióban a 2014-2020 közötti Európai Uniós költségvetési periódusban a különböző jogállású településeken (a táblázat nem tartalmazza a megyeszékhelyek adatait)

Table 7: Characteristics of the applications financed by the Regional and Settlement Development Operational

Programme in the Northern Great Plain region during the 2014-2020 budgetary period by settlements of varying administrative status (the data of county seats is not included)

\begin{tabular}{|l|c|c|c|c|c|c|c|c|}
\hline & \multicolumn{2}{|c|}{$\begin{array}{c}\text { Hajdú-Bihar } \\
\text { megye }\end{array}$} & \multicolumn{2}{c|}{$\begin{array}{c}\text { Jász-Nagykun- } \\
\text { Szolnok megye }\end{array}$} & \multicolumn{2}{c|}{$\begin{array}{c}\text { Szabolcs-Szatmár- } \\
\text { Bereg megye }\end{array}$} & \multicolumn{2}{c|}{$\begin{array}{c}\text { Észak-Alföldi } \\
\text { régió }\end{array}$} \\
\cline { 2 - 10 } & $\mathrm{A}$ & $\mathrm{B}$ & $\mathrm{A}$ & $\mathrm{B}$ & $\mathrm{A}$ & $\mathrm{B}$ & $\mathrm{A}$ & $\mathrm{B}$ \\
\hline járásközpontok & 35,2 & 43,8 & 28,2 & 38,8 & 27,7 & 23,2 & 29,7 & 33,8 \\
\hline egyéb települések & 64,8 & 56,2 & 71,8 & 61,2 & 72,3 & 76,8 & 70,3 & 66,2 \\
\hline
\end{tabular}

A - a támogatásokból való részesedés (\%), B - az állandó népességből való részesedés (\%),

Forrás: palyazat.gov.hu és a teir.hu alapján saját számitás

A Környezeti és Energiahatékonysági Operatív Program (8. táblázat) esetében rendkívül erős koncentráció tapasztalható: a támogatások csaknem $90 \%$-a érkezett a járásközpontokba, miközben az érintett települések a régió lakosságának alig több 50\%-át tömörítik. Ennek hátterében az a korábban már ismertetett tény áll, hogy az fejlesztésekkel érintett épületek (pl. középiskola, kórház, rendőrkapitányság épülete) döntő része olyan központi funkciót biztosít, amelyek a járásközpontokba tömörülnek.

8. táblázat: A Környezeti és Energiahatékonysági Operatív Programból finanszírozott pályázatok jellegzetességei az Észak-Alföldi régióban a 2014-2020 közötti Európai Uniós költségvetési periódusban a különbözö jogállású településeken

Table 8: Characteristics of the applications financed by the Regional and Settlement Development Operational Programme in the Northern Great Plain region during the 2014-2020 budgetary period by settlements of varying administrative status

\begin{tabular}{|l|c|c|c|c|c|c|c|c|}
\hline & \multicolumn{2}{|c|}{$\begin{array}{c}\text { Hajdú-Bihar } \\
\text { megye }\end{array}$} & \multicolumn{2}{c|}{$\begin{array}{c}\text { Jász-Nagykun- } \\
\text { Szolnok megye }\end{array}$} & \multicolumn{2}{c|}{$\begin{array}{c}\text { Szabolcs-Szatmár- } \\
\text { Bereg megye }\end{array}$} & \multicolumn{2}{c|}{$\begin{array}{c}\text { Észak-Alföldi } \\
\text { régió }\end{array}$} \\
\cline { 2 - 9 } & $\mathrm{A}$ & $\mathrm{B}$ & $\mathrm{A}$ & $\mathrm{B}$ & $\mathrm{A}$ & $\mathrm{B}$ & $\mathrm{A}$ & $\mathrm{B}$ \\
\hline járásközpontok & 94,9 & 64,8 & 94,1 & 50,2 & 84,4 & 38,9 & 88,4 & 51,1 \\
\hline egyéb települések & 5,1 & 35,2 & 5,9 & 49,8 & 15,6 & 61,1 & 11,6 & 48,9 \\
\hline
\end{tabular}

$A$ - a támogatásokból való részesedés (\%), $B$ - az állandó népességből való részesedés (\%),

Forrás: palyazat.gov.hu és a teir.hu alapján saját számitás

\section{Összefoglalás és javaslatok}

A tanulmány legfontosabb megállapításait az alábbiakban lehet összefoglalni. A 2014-2020 közötti költségvetési periódusban - hasonlóan az ország viszonyokhoz - az Észak-Alföldi régióban is jelentős 
összegü Európai Uniós támogatás állt rendelkezésre a megújuló energiaforrások felhasználásának elterjesztése céljából. A támogatások területi megoszlását ugyanakkor több tényező is befolyásolta.

Egyrészt az egyes területi egységek társadalmi-gazdasági fejlettségi szintjét kell megemlíteni, amelynek a hatása két területen is megfigyelhető volt. Makrotérségi szinten említhető meg a fejletlenebb területi egységek nagyobb pályázati aktivitása (Észak-Alföldi régió), a jobb pályázati eredményesség és a nagyobb átlagos projekt-nagyság (Szabolcs-Szatmár-Bereg megye). Mikroszinten (járás szintje) elsősorban azt lehet kiemelni, hogy a fejletlenebb térségekbe relatíve (egy állandó lakosra számítva) nagyobb összegü támogatás érkezett, és mivel ezen pályázatok finanszírozása a legtöbb esetben $100 \%$-os volt, ez nagyobb beruházás is jelentett.

A második fontos tényezőnek az egyes települések népességszámát lehetett tekinteni. amely esetében ugyanakkor már különbség figyelhetö meg a két operatív program között. A Terület- és Településfejlesztési Operatív program esetében a kisebb (2.000 fő alatti) települések kedvező helyzete figyelhető meg (magasabb a támogatásokból való részesedésük, mint az állandó népességből való részesedésük), míg a Környezeti és Energiahatékonysági Operatív Programnál fordított a helyzet.

Harmadrészt hatással volt a támogatások térbeli eloszlására a települések közigazgatási szerepe is, ugyanakkor itt is jelentkezett különbség a két operatív program között. A Környezeti és Energiahatékonysági Operatív Programból finanszírozott beruházások esetében a járásközpontok felülreprezentáltsága volt jellemző, míg a Terület- és Településfejlesztési Operatív Programnál nem lehetett ilyen tendenciát megfigyelni.

Az eltéró ágazatok miatt igen nehéz a kutatás eredményeit a korábban elvégzett, és a „Bevezetés, témafelvetés" alfejezetben ismertetett vizsgálatok következtetéseivel összehasonlítani. Az egész országra kiterjedő elemzés (Hajnal - Medve-Bálint, 2016) fontosabb megállapításaival (pl. a gazdagabb és népesebb települések kedvezőbb helyzete) való ellentét minden valószínüség szerint arra vezethető vissza, hogy az érintett tanulmány az összes operatív program keretében érkezett forrásokkal foglalkozott, míg a jelen kutatás középpontjában egy szükebb, speciálisabb sajátoságokkal rendelkező terület állt (pl. helyi önkormányzatok fontos szerepe a pályázatok esetében, több konstrukciónál 100\%-os finanszírozás). Vizsgálatunk ugyanakkor megerősítette az encsi járásban végzett kutatás (Nemes et al., 2017), azon következtetését, hogy a környezetvédelemmel és az energiával foglalkozó pályázatok esetében a járásközpontok preferáltsága figyelhető meg. A megújuló energiaforrások felhasználását támogató pályázatok térbeliség elemző tanulmány (Czimre et al., 2019) azon következtetését is megerősítette kutatásunk, hogy a településnagyság növekedésével emelkedett az egy pályázatra jutó összeg.

A kutatás eredményekre támaszkodva alapvetően az a javaslat fogalmazható meg, hogy a későbbiekben is törekedni kell arra, hogy gazdasági-társadalmi szempontból elmaradottabb járások, illetve kisebb települések esetében olyan pályázati kiírások jelenjenek meg, amelyek lehetővé teszik azt, hogy az ő körükben az átlagosnál nagyobb mértékben valósuljanak meg ilyen jellegü fejlesztések.

\section{Köszönetnyilvánítás}

A publikáció elkészítését az EFOP-3.6.1-16-2016-00022 számú projekt támogatta. A projekt az Európai unió támogatásával, az Európai Szociális Alap társfinanszírozásával valósult meg.

\section{Irodalomjegyzék}

Afsharzade N., Papzan A., Ashjaee M., Delangizan S., Van Passel S., Azadi, H. (2016): Renewable energy development in rural areas of Iran. Renewable and Sustainable Energy Reviews, 65, pp. 743755.

Benedek J., Sebestyén T.T., Bartók, B. (2018): Evaluation of renewable energy sources in peripheral areas and renewable energy-based rural development. Renewable and Sustainable Energy Reviews, 90, pp. 516-535.

Blindheim B. (2015): A missing link? The case of Norway and Sweden: Does increased renewable energy production impact domestic greenhouse gas emissions? Energy Policy, 77, pp. 207-215. 
Brisbois M.C. (2019): Powershifts: A framework for assessing the growing impact of decentralized ownership of energy transitions on political decision-making. Energy Research \& Social Science, 50, pp. 151-161.

Czimre, K., Kozma, G., Teperics, K., Szabó, Gy., Fazekas I. (2019). Renewable energy resources in new Hungary development plan: some general and spatial characteristics. International Review of Applied Sciences and Engineering, Volumen, No 2, pp. 183-191.

European Commission (2010): EUROPE 2020 - A strategy for smart, sustainable and inclusive growth. Communication from the Commission. COM(2010) 2020, Brussels

Európai Unió Hivatalos Lapja (2018): Az Európai Parlament és a Tanács (EU) 2018/2001 irányelve a megújuló energiaforrásokból elóállitott energia használatának elömozdításáról, Brüsszel, L 328/82209.

Gao H., Xu S., Liu Y., Wang L., Xiang Y., Liu, J. (2020): Decentralized optimal operation model for cooperative microgrids considering renewable energy uncertainties. Applied Energy, 262, 114579.

Gyurkó, Á. (2020): Az Észak-magyarországi statisztikai régió idegenforgalmi térszerkezetének általános jellemzői és a változásai az Európai Unió turizmusfejlesztési források tükrében 2004-2019 között. PhD-értekezés, Debrecen

Hajnal, Gy., Medve-Bálint, G. (2016): Fejlesztéspolitika térben és időben: az Európai Unió fejlesztési célú támogatásai Magyarországon - 2004-2015. In: Tózsa I. (szerk) (2016): Humán tér-kép, A humán és fejlesztéspolitikai tényezők földrajza Magyarországon. E-Government Alapítvány, Budapest

Hajdú, D. (2021): Az Európai Uniós forrásból támogatott munkaeröpiaci képzések területi eloszlása Borsod-Abaúj-Zemplén megyében. Studia Mundi - Economica, Volumen 8, No 1, pp. 24-36.

Innovációs és Technológiai Minisztérium (2020a): Nemzeti Energiastratégia, 2030, Budapest

Innovációs és Technológiai Minisztérium (2020b): Nemzeti Energia- és Klímaterv, Budapest

Járdány, K. (2021): Borászati üzemfejlesztési támogatások területi megoszlásának vizsgálata Magyarországon 2014-2020 között. Észak-Magyarországi Stratégiai Füzetek, Volumen,18, No 1, pp. 58-71.

Koncz, G., Nagyné Demeter, D. (2015): Megújuló energia projektek közösségfejlesztö szerepe. Economica, Volumen 8, No 4/2, pp. 142-151.

Krishan O., Suhag, S. (2019): Techno-economic analysis of a hybrid renewable energy system for an energy poor rural community. Journal of Energy Storage, 23, pp. 305-319.

Michalkó G., Lontai-Szilágyi Zs., Kiss K., Martonné Erdős K. (2017): A megújuló energia szerepe a falusi turizmus és a magyarországi falvak modernizációjában. Turizmus Bulletin. 17. évf. 1-2. sz. pp. 35-44.

Mittal S., Dai H., Fujimori S., Masui T. (2016): Bridging greenhouse gas emissions and renewable energy deployment target: comparative assessment of China and India. Applied Energy, 166, pp. 301313.

Nemes, G., Jeney, L., Varga, Á., Juhász, P., Korompai, A. (2017): Megvalósult és elmaradt szinergiák a fejlesztéspolitikában - Uniós és hazai támogatások kölcsönhatásai földrajzi keretben (Szinergiák). OTKA Projekt jelentés, Budapesti Corvinus Egyetem, Budapest

Nemzeti Fejlesztési Minisztérium (2010) Magyarország Megújuló Energia Hasznositási Cselekvési Terve 2010-2020, Budapest

Paladin A., Das R., Wang Y., Ali Z., Kotter R., Putrus G., Turri R. (2021): Micro market based optimisation framework for decentralised management of distributed flexibility assets. Renewable Energy, 163, pp. 1595-1611.

Panwar N.L., Kaushik S.C., Kothari, S. (2011): Role of renewable energy sources in environmental protection: A review. Renewable and sustainable energy reviews, Volumen 15, No 3, pp. 1513-1524.

Squalli J. (2017): Renewable energy, coal as a baseload power source, and greenhouse gas emissions: Evidence from US state-level data. Energy, 127, pp. 479-488.

Woch F., Hernik J., Linke H. J., Sankowski E., Bęczkowska M., Noszczyk T. (2017): Renewable Energy and Rural Autonomy: A Case Study with Generalizations. Polish Journal of Environmental Studies, Volumen, 26, No 6, pp. 2823-2832.

https://www.palyazat.gov.hu/tamogatott_projektkereso (letöltés dátuma: 2021.02.02.)

https://teir.hu (letöltés dátuma: 2021.02.02.) 